な筒所も多々見られたるが甚だ迷惑なるここ で我國民は一に防空の知識走克分理解して登 火の如きは一登も外に漏らさじこいふ決心で 望まれたい。管制の不徽底は非國民こ呼ばれ ても過言ではないこ思。，(一登の灯敵機灰 招く)

1. 種類 屋外燈の一部消燈

去る 8 月初旬頃關東一圓に屋外燈一部消燈 の警視聽令が施行された彼の北滿國境張鼓峰 事件の萬一の鹪に施行されたものだこいふ。

2. 警或管制之れは敵機襲來の恐れ有る時 に行ふ。

3. 空襲管制之れは敵機襲來の危險ある時 に行ふ。
然し乍ら例外ありて空襲管制時でも

1. 軍に關係せる所

皇 室

大使館，公使館等其他

2. 地方長管の指定によるもの)

3. 建築物, 車輛, 地下室,

4. 人命救助, (例救護所には特設の灯觉附 ける) 渻防等。

5. 警察署長の許可焁得た時 消燈の外に滅光, 遮光, 漏光制限等あり。 滅光 1. 3 平方米に 10 燭光以內の割合,

2. 電登の大さ名50烛光以下にする

3. 光を直接外に出さない樣

沿工場其他の大建築場には漏光制限あるも の規則は別に定めてあるが必要なし。

\title{
杏林今昔之感一名順天堂逸話 (其八)
}

\section{元順天堂醫事研究會 田中義 雄}

杏林今昔之感 一名順天堂逸話目錄

1. 守錢奴患者の入院

2. 先入圭となり自ら瀨病と信す

3. サア今直癒して吳れ

4. 嗚呼是は全く水天宮樣の御萨じや

5. 漢法醫者包蕉の手術

6. 院長の聲色良使つても駄目だ

7. 檢尿の殘餘忽ち變して香水に化す

8. 前田上圊の貴人を篤罟す

9. 敀外朝櫻の眺矚

10. 是は何の機械げらふ

11. 山口呩助先生の諧謔に照山黄金老时く

12. 三人上戸

13. 杏林冕話

（1）釣客魚走釣らんと欲して自己痤釣万

(2)富豪の阿艮切られて却て生方得

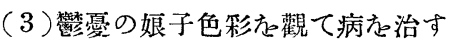

\section{1. 守錢奴患者の入院}

明治 25,6 年の頃なりき順天順醫院南樓上 中通 中央满室に龄 50 幾歲新井 $\bigcirc \bigcirc$ 衞門こ稱 する胃加答兒の病症を以て入院せし者あり此
の患者は昔順天営の門人にして我國最初の女 醫高橋瑞子の紹介に係れり患者は毫も同氏の 命令を聞か古不消化物学契乙日々重症に陷い 万炎以て百少說得して濑やく順天堂に入院せ しめし者なりミ云ふ。聞此の患者は最初上京 の際囊中僅に朱堤 30 錢驾所持せしのみなり しが爾來諺に謂ふ喰少领ずに貯財して今は三 十萬圓の富を有せりこ, 然れごも銀行會社其 の他に預ける時は破產, 分產有万琶到て公 債證書登購求せ乙も是亦出火其の他の多害の 患ある⿸以て何時にても持逃出さる>在圖り 奉負葛籠に納入して書夜守護する定能事ミ第 せり故に入院當時は入込 (當時順天堂の一室 に多人數同室する亚謂ふ）安價の病室存欲し しも盜難学恐るっミ刃他に一種の考を有し彼 には一生一代の舊發定键行して一人住の病室 に入院する事こ䍃せり如此狀態なる等以て親 戚は勿諭親兄弟も音信不通, 知人は惆れて近 寄る者なし，彼自からは却て是军得こせり， 每:夜四邊人菲靜なる蛋待ちて, 静かに病床に 
起坐し，音響を警武して，枕頭安置の资員暮

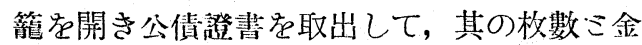

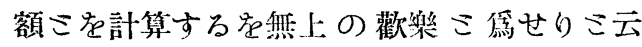
s。

余は一日此の隣室に新入患者有り其の現症 を記載せんこ欲して至りしに新井の室に突然 怒號吨咜の大聲あり，何事ならんこ耳を傾く れば，彼曰く，芑の病氣は順天学の立派なお 醫者樣が見て居らる>のに㳔は醫者にも非す して病人㒻舞ひに來ればこて何の谷かあら ん哉, 案するに己の病氣を見舞ふにあらすし て此, 葛籠觉見舞ひに來たりしならん,己はま だまぜ死なっひよ，其樣他人の物を目賏けす に自分で働きて自分で貯金せよ速く歸れ歸れ ミ追ひ拂い歸らしめたり但し此の見舞人は田 舍人にして所琱ありて上京せしに○○潇門病 氣け覊めに入院せしこ聞き本素はこもあれ病 中定めし知己なきに困しむならんこ思性て態 々尋ね見舞ひしなりこ云ふ而して彼が入院當 時の食物は米码に 1 食 2 個の鷄卵を與へられ たれごも2 個の鴙卵在 1 回に食す号事は彼末

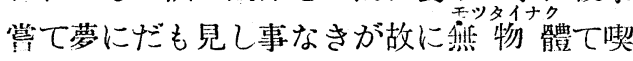
する事能はす看護婦に請ふてて私は 1 食に 1 個 を以て足る>から 1 個の鷄卵代價を入院料か ら差し引き吳よこ掛合しも逐に容れられす仕 方なくなく日々 3 個を貯藏して灵好折もあら ば，代金に撸へんものこし唯 1 食 1 個のみを 喫食せり而して其の喫食の際は破摧の卵殼內 に指を插入して殘餘附着の溶液定拭ひ其の指 草賞めて毫も存在せざるに至らざれば止めす こ云ふ虽持人皆謂。抑了守錢奴なる者は师に 多しこ雖ぶも如此は淺ましき極度にして誠に 唶々たる者なりこ若夫れ現今ならば人皆謂は ん如此は是成金王の嘖々たる者にして垂涎三 尺守錢大博士こ稱灒するならん乎。

\section{2. 先入主となり自ら癩病と信ず}

1 日龄 30 幾歲の一男兒來院診を請心唯見 乃全顏面は左右耳殸, 口唇, 鼻翼, 左右上下 の眼瞼こ共に將又左右兩手は唯手掌及び爪床
のみ尔除きて乎背兩側から前膊下 3 分の 2 に 互りて悉く暗黑褐色痘痕狀の尒點瘢痕责以て 傷害せらる〉虚認む患者曰く今学去る 3 ケ月 前當院に來りて診在請ひしこ雖ぶも當時癩病 は治荧病院に請ふも覓なし草津に行くに如す ミ焦して至りしに唯入浴のみにては治癒する ものに非す全身炎治を施すべしこ注告せられ 直に醫師に就いて炎治虏請ふてて現狀如此し人 皆謂ふ抑々癩病なるものは全身敦れの部分に 尒灼するも決して熱氣在感覺せずに反して 氏は熱惱に堪一難しこ言ふ是恐らく癩病に非 ざるや必せりこ我此の話を聞きて牛信牛疑他 の患者に就て尒治の賽際を仔細に目揧すれば 需に熱惱なきのみならす溫嗳も亦自覺せざる もの>如し立に至りて出京診在請ひ確定せん ミ欲して來院せりこ言ふ。

帳簿を閱して初診の祜名を檢すれば顔面潪 疹「レプラ」の訴人ありこ書せり故に患者に問

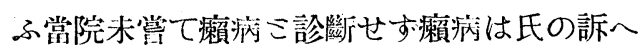
なりミ患者口く我は名古屋の產なり一日顏面 吹出物せり煩㾕に堪へざるを以て某醫に診を

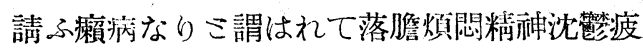
勞の極に至りて最早斯くなる上は整们に治療 を請ふも無谷こせり時に人あり謂ふ草津の溫 泉は有效現著なりこ直に意を決して故關を出

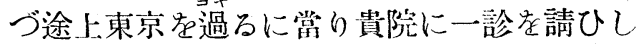
も先入圭こなりて最早他の病名は耳に入らす 以て草津に走りて炎治在請ひ如此き癩病患者 炎傷の容貌こはなりたりこ。

蓋此の患者は自己の一身虎處するに輕卒な りしは他に其の比を見方疾愚甚しきは寧乃悲 歏の極めなれごも一般俗人すら炎治灼熱の感 ある者は獺病に非ざるを知る況んや身は譬ひ 庸醫にして他の疾病は診炏し能はざるも久し く癩病の集合所たる草津に佳して毁に幾千人 の炎治を䉆し來り今此の患者に對して熱灼煩

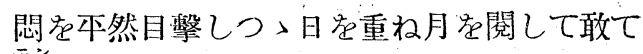
言を忍びしは抑了何事ぞや當底常識军以て解 する事能はざるなり。 
古歌に云く陸奥の安達の原の黑塚に鬼籠れ りミ云ふは信こかこ但し今の草津は安達郡に はあらざれごも恐らく此の庸醫は往時の鬼の 末裔なららん乎将攵此の患者をして事玆に至ら しめたる名古屋の庸醫は是亦如何なる親の鬼 子なる乎我此是蛋知らざれぶも彼等兩者は遠 からす効病に罹ら乎又生ながら焦熱地獄に 陷媳し夜書絕八市阿鼻叫喚の呵責陽報は恐ら く兑る〉事は能はざるならん乎。

因に云ふ上記の當時一日群婜縣安中の俅人 龄 20 年代の若夫婦 2 歳の嬰兒学懷にして診 在請ふ其の夫其の婦の顏面は一種の白色にし て亦一種の光輝尚り夫の盾毛は毁に渻失し頭 髮も亦夫婦共に牛ば以に涗毛して皮膚名透見 し指趾の尖端は將に潰鼠を初めんこ第るの狀 あり 一見白癩なるは知るべきな而して其の 抱擁せらる嬰兒は外見上䒜注健全なる者の如 乙今此の白瀨慈母の懷中に抱かれて乳嘴を口 に含み他側の乳房名玩琵しつ入無心に母顏を 仰見し嬉々こして笑各含めるは却て人をして 一見戰慄寧乃箳慙酸鼻の感あらしめたりき。

當時順天管の䇴局一出入せし洋服商德海屋 の番頭某今其姓名在忘失せしが酦に二十有餘 年前喉頭結核学以て永眠せり。彼生前に日く 草津の下流に一部落あり日本全國富豪癩病患 者の聚絡なり故に博士あり學士あり文人墨客 あり有ゆる階級ありて自由に要朋资便ずるも 其の地に得るここ能はざる物は一通の書狀に 第替券を附して若夫れ西川商店に郵送すれば

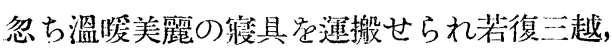
白木，高島屋等に揆附すれば立所に美服高等 の調度品存到達せり而して彼等は自己の企望 に準じて大小佳所を建燢せり旅館も亦求めに 應じて自由なりしミ云ふ。

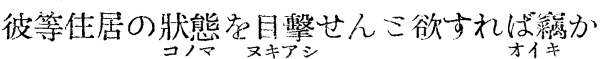

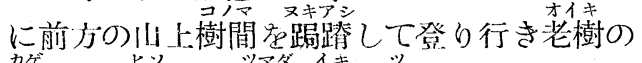

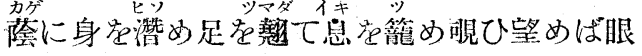
下に目整し得可し即ち其の富豪の一例を擧ぐ れば美装一室の床上には價ひ幾干萬金絕へて

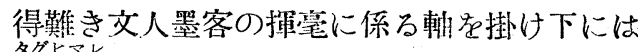
類稀なる花瓶に花痤し香爐其の他珍稀の 置物は皆是，之に相賞高價の珍品なり又㑡方 冠棚の)書畫帖其O他の)書帙は中は如何が見る ここ能はざれるも毫れ得難き珍書たるは謂は ずもがな而して其の一側には金屏風を立巡ら

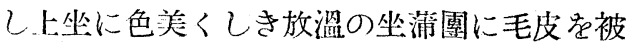
雨せし上に善美量極めし美服差着け脇息に凭 り喫煙せる上公は國貞國重等の描寫に係る时 舍源氏の光氏にあらざれば舊劇舞臺の殿樣を 賽地に觀るが如く將又是に侍づく女中ミ゙もは 是亦身に裾模樣の振袖に帶在やの学に結びて 裙を引き茶菒死目分に捧代て悲しく未人に 供する狀態は是亦田舍源氏の繪卷にあらざれ ば舊劇場裡の殿中活人畫ならでは觀るここ能 はざる有樣なりけり奌。

然り而して人若一度彼等の頭首特に顏貌や 手足觉一見すれば倠か其の限貌に喫警々倒せ ざる者あらんや即ら彼等の頭影眉毛は睫毛こ 共に脫落し其の結節癩に在りては恰も鹿子䬼 虎泥土に污染して眼鼻学附けしが如く其の白

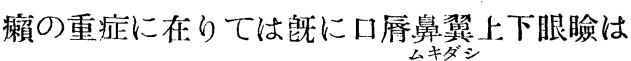
耳殼こ共に脫落缺損し齒牙唯剥出し俗に所謂 「ノッペラポウ」こなれり彼等の未标失明せざ る者は日々新聞军償み小說觉閱して意中如何 の感ある乎，蒷に哀れなる天刑病，斯くなり

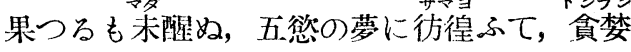
更に飽くここ水知らず，事々物々に對しては 卜度思想に閉馛られて，妄念情慮去り遣らす 百鬼夜行の夫れならなくに, 夜書扮裝乃六道

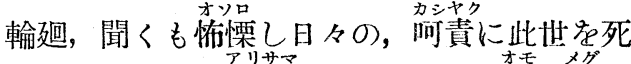
して逝く，其の狀態を今立に，彼是顧ひ迴ら せば，自己完全生產きて，80歳の今年迄，い こ健康に你命人し，此の莘運多き身にしあれ

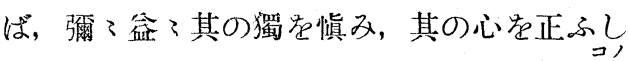
て, 十少坐剑那一物飞把握し，日々是好日現

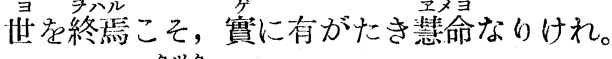

\section{3. サア直今澸して曼れ}

一娘慈父に伴はれ來りて診莡請。幼時左側 
の無名指及び小指の掌面火傷に罹り屈曲して 伸展せす庸䣽觀て以て㾻痕を切斷すれば伸展

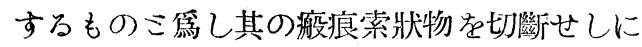
庸醫止血の法点知らす手腕の脈搏部に綿球を 宛て麻繩を以て二重に緊縛せり患者疼痛に㙋 人亦夜中其の一條军切斷せり庸醫見て以て之 を吡す然れごも疼痛甚ゆる能はず遂に全部切 岰除去せしも指頭站に手掌の感覺鈍麻し漱々 變色の狀ありしを以て慈父驚愕して其の醫を 伴ひ順天堂に來りて診を請ひしこ云ふ進先生 一見せらる>や慈父闑ふて曰く此の指治すべ き乎こ先牛曰はく此れ是を見よ兓に變色せり 急ぎ入院治療すれば助かるやも謀り難しこ雖 ふも受合ふここ能はすミ慈父忽ち待つて被 下しやいこ絕叫し控等に飛び出し庸醫の胸襟 定兩手に緊握率引し來り雚んで日く此處の先

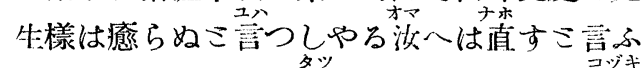
からサア癒してくれ直た今癒して吳れこ小突 廻し突然一場の喜劇否悲副を演ぜしを以て淮 先生は驚きて明中此の者共在彼方八作ひ何こ か處置せよミ余は此の兩人民作ひ別空に至り 先づ父親を喻して曰く事玆に至りては如何に 憤怒々號するも其の收なし月時も速く入院 治療を施さぶれで指を助くるここ能はすこ復 庸醫を招けば彼落淚合掌して余を拜し先生樣 何卒御助救下さいら余に救助虹請ふ余其の入 院料其の他 $の$ 費用蛋拂はしむべく談ぜしに庸 醫喜んで承引せり。

入院後直に順天堂傳來の「バット」法を施し 溸やく全指の脫落を防ぎ逐に全きを得たり而 して余は庸醫に對し洀狼內の血管は把握容易 のものに非方已後は夫れ是を知らすして销り に手を下す可らずに將來友訓誡して歸鄉せし めたり。

因に售ふ「バットミは其の名の如く入浴の 意にして先づ金㬈現今ならば洗面器內に約 40 度內外 (㙋一得る溫度) の溫湯在 7 分目注入乙 其の溫度䎞終始同一に保たしめんが鹪めに火 鉢に載せ置きて或は側らに沸䲲湯蛋入れたる
鐵瓶在火鉢に載せ置き時々注入して其の溫度 を一定し其の湯中に患部譬へば脫㥀足部（下 脚に互れば「バかッ」を探用す)等を浴浸し約 1 時間朝夕 2 包宛祭日繼續すべし蓋此くの如 くする時は血液循謤の灌溉宜しき在得るが故 に脫疽の如きは忽ち「デマルカ」線を生じ上記 の如き場合に在りては效力極めて現著なり蓋 此の「バット」は溫兴法の理ミ等しくして唯其 の阎上せし物に觀るべきなり。

\section{4. 鳴呼是は全く水天宮樣の卸蓼じや}

歲は維明治幾年なりしか今は忘失せしも末 杏林界に耳悬咽喉科の耳の゙も非ざりし頃な

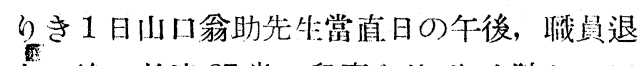
去の後一老婆 67 歳の兒童を伴ひ來院して曰 く今より一週日前誤りて裳錢銅貨党祭下せり 喉に㢡りて下らす諸處の醫仰に除去を請八ミ゙ も能はす遠く神奈川から來りて攝除を請ふ こ。

先づ患者蛋椅子に凭らしめて余は其の後う より患者の頭首在仰问く几腔こ食道在一淔線 に固定せり山口先生左僛 $($ )示, 中, 兩指を几 內に送人し其の指間に遗物揖の挾端在挾みて

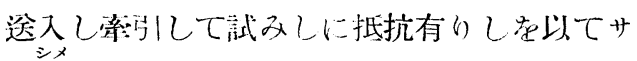

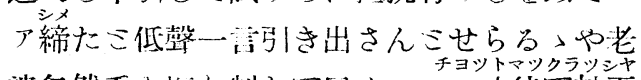

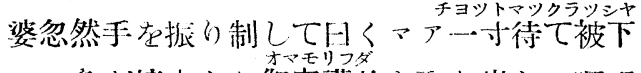
いミ急ぎ惇中より御守護札を取り出して㗅喉 の外部を撫降しつ>㫛交名唱へ檮請しつ>サ ア宜い, 郎ち山川先生率引てて骤出せらるれ ば老婆脑撫降して曰く鳴呼有難し有難し是は 全く此の水天宮樣の御䕬じやこ御守護札名戴 けり田舍老婆の朴直なるには一警を喫し山口 先生ミ余ミは唯咧然こして互に顏面学見合せ しのみ。

\section{5. 漢法醫家包荎の手術}

恒久先牛御在世の時なりき一漢法䇥阨あり

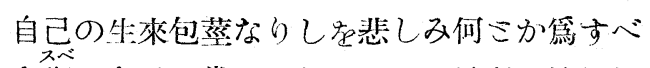
き衔なき乎こ常に目擎して百法思考の結果包 皮の外緣妴少しく切除すれば自由に滑脫し得 ベしこ焦し意在決して一空に閉籠り左指に包 
皮を摘みて延張し其の外緣に沿ふて剪伐せり 漢醫元來止血の法を知方音伐其儘なるを以 て出血容易に止まらざりしも寻に其の量多量 ならざりしが故に先創面に沃度「ホルム」蛋散 布し次で龜頭こ包皮の間に充填し更に㓌蔡の 外面一般に散布せしが故に恰も陽蒸の阿部川 䬦觀るが如し而して後線君以て被覆し䁚鼻褌 に納めて絎军終はれり爾來日を經るここ2 月包皮意の如く滑脫移動せざるのみならす包 皮の創面垃に龜頭の外皮沃沃度「ホルム」の刺 戟に因り白色肥厚せしを以て如们こも第すこ ミ能はす遂に出京來院治を請ひしこ云ふ。

時恰も由獨逸醫學雜誌に(雜誌 0 )名尔忘火 せり）八アゲドルン氏考案の包签手術式军報 告せしあり恒人先特執刀是を試みんこ欲せら れ法の如く患部军清洗沾毒して先直射在執つ て繫帶反側の包皮を內外共に縱徑に䁚伐し二次

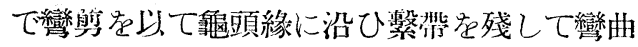

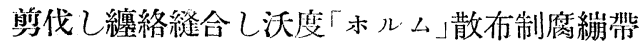
を施して衡を終はる但し直尊泣に彎剪学々伐の

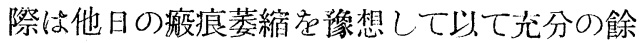
裕を殘留せずんばあらざるは余が言を俟ざる なり急ハァゲドルン氏の術式は從來の術式に 比すれば瘏痕萎縮に對して龜頭の頸部在絞管 するここ無き䟪甚理ありこ焦せり。

\section{6. 院長の馨色を使つても駄目だ}

明治 25,6 年 $の$ 项盛夏酷熱蒸浱人歨煩はし 屋上の监子舌蛋吓くの日余は同僚豐田常雄君 こ共に午後の院務を終りて研究室に歸り直に 脊廣(當時手術着未げ你在せ方) 莡脫して放擲 して赤裸々にし共に仰卧し一枚朝刊新聞紙学 取り互に左右の兩端妾引新引頭首を近べて各 各閱讀の際玄關障子の破孔学战き菅野は居な

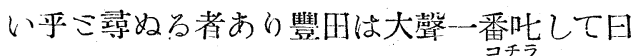
く誰げ失敬な障子の破孔勧覘いて此處へ這入 れミ余も亦曰く爻んな院長の蹈色蛋使つても

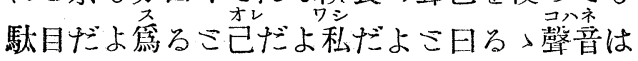
確に院長なれば豐田は蕉愕一散に講堂に遁瓮 せしも余は逃的避れて院長を置き去りにする
ここ能はす直に鴨居の釘に影垂せし單衣を取 り急いで左腕を右袖に通し右腕定通さんこ欲 し〉も能はす其の儘右手に單衣を取り股間に 抱八込みて正坐し左手を突で恭や乙く带こめ ば院長は留よ宜よ畒野が來たら私が探して居 つたこ傳言して吳ミ歸られたり豐明はすずす ご出來り二人で警たナアこ余ば初めて單衣の 右袖に左腕を通し右腕更に通すべきなきを了 解し其の愊急かたの甚げしき炎發見せり而し て兩人漱やく單衣を着せし時䠉野氏來らる院 長の傳言空通ずれば今彼處で遇たこ日ふ余は 今此の出來事を話せしに宜なるかなぶうも何 だ乎戀げこ思へりこ豐间君銷然こして曰く余

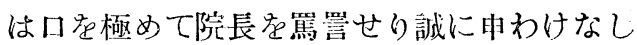
こ余日く白圭の缺たるは三復すべし其の言の 缺たるは行るふべがらす㯖むべきは口なりけり こ豐田日くなんだ君げつて篤䍗したじやない か余日く夫はそうこ君は敢て惡心あるにあら ざるは院長も亦是㕝知れり安心し給へ夫れよ りも我等今日は團十郎こなり左團次こなりて 假名手本忠臣藏の夜討其の儘を實地に演じて 院長の觀覽に供したり院長は時ならぬ滑嵇演 劇一慕荧觀方事在得られ今頃は思ひ出して苦 笑せらる>ならんこ三人共に阿阿々

\section{7. 檢尿の殘餘忽ち變して香水に化す}

今在去る 30 年以前の事なりき賞時熟生に 桑折某こ稱する一人あり其の第人鼻に傑れて 高佔性沈着にして語少なし或上曜日の午後余 の檢查室に來りて曰く余は「リテラッウル」を 調んこ欲す机の借用を請ふこ余之を諾して歸 路に登れり，整くして熟生村上某來り檢查臺 上に二八香水の壜ある学見て忽ち警て曰く人 は見かけに低らぬ者なりあの朴直の田中君で も香水を使用せらる>かナアこ其の木栓を拔 きて香邑嗅げば放香馥郁たり乃ち机に歌り一 心不狦に閱蒷せる桑折君の頭亡に墨滴すれば 警きて顧み君何䉆当乎村上曰く見玉へこ二八 香水を示し互に振奬け居る處へ今一人（姓名 を忘失せり）入來り三人交々壜を取りて或は 
㖣着或ば登衣或は「ハンカチイフ」等に浸潤せ しめて顏に塗り手に塗り頭に塗りて遂に其の 5 分の 4 定遣ひ盡せり一人漱やく氣附き斯く の加く多量を使用すれば田中君に怒らる>や 必せりこ初めて其の使用在中止せり一人日く 少しも香はせぬじやない乎及一人木栓在拢き て香を嗅がしめて曰く和製の香水汹舶來に如 すこ他復曰く香水は舶來殊に佛國彆に限る こ遂に殘餘の二八香水を檢查臺上に安置して 歸熟せりこ云ふ。

余一日隔て>月曜日の朝出勤の際村上走り 來り臺上の二八香水を指ざし問ふてて日く此は 是何です乎余日く是は看護婦塩原の尿なり善 公 (小使の名) は捨つる点れしならんこ取り て不梁瓶裡に投擲すれば村上君餐き日くヤア 大變げ大變げ一咋日（士曜日）全く香水なりこ 思惟桑折君こ某君こ三人共に衣服に移しく浸 潤せしめたり慨に乾燥して今更如何こも䉆す 事能はすこ及走りて桑折君こ他の一人こに是 を告ぐるや當持滑嵇こ諧諕を以て喜戲の親玉 長瀨君の耳に入りしかば何在か溜るべき忽ち 「ナンジャ夷等三人で塩原の小便を舐たのか 兰人日くなに䑛っものか一長瀨君日く顏面に 塗布せ乙際口辱に附著せし尿を舌䑛啜して喠 液こ共に與下したるや必せり是㴧ち余が惟ふ 通り君等三人塩原の小便策甜めて喜んで居る ではない乎ミ三人既に日在經るここ三日今更 如何こも笘すここ能はすゲィゲィ嘔氣を催な し隀液を叶きても其の效更に在るここなし又 三人互に競り合ひ先觉等ふて使用せしが故に 誰を怨みん樣もなく小便浸潤の自己の衣服庄 默視轻嚾するのみ然り而して遂に熟中のみな らす樂局會計看護婦等病院中誰一人知らざる 者なく順天学設立以來の珍事こして評制高く ぞなりにける。

因に言ふ看護婦塩原は元來「ハイカラ」女な り彼は患者に佛國製香水の明壜を貴ひ當持初 めて發賣せられし二八番水(和製香水の元租) 学購求して此の明境に移入乙見る人をして私
は佛國製祭水を使用せりこ思はしむるの策略 なり此の日彼は少しく身神不快を以て塾生に 診农請ひしに檢尿の必要あり余に蛋白有無の 檢查を請。ふへく命ぜられたり幸ひ此處に二八 香水の明䭪あり新らしく且清浮なればこ清洗 して尿を入れしに稀琥暏色清㐿透明なりしが 故に其の內容の何たる在知らざれば一見二八 香水なりこ思惟するは必然なり沅んや一度木 栓の浸潤の香を吸覺すれば放香馥郁たりしが 故に三人共に此の失敗を演ぜしは敢て理なき

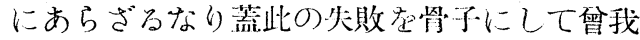
迺屋五郎に演ぜしもれば忽ち大入叶の札を販 布せらる>は必定ならん。

\section{8. 前田上園の貴人を䍗る}

垡は明治二十幾年なりしか余は今諳得する に由なけれごも正に是盛夏酷熱整日赫々人を して苦ましむるの日であつたの络今でも確に 記憶せり此の)日余は午後腎者待合宾の上等溜 に在りて咃語に餘念なき折しもあれ恩阮淮先 牛來りて後；の則に上圊せらる次で熟生前田 來りてト園せんこ欲ししも其の戸の開かざる は解に人ある定知り余の側に來りて椅子に凭 り整らく待りしも獎へすや有りけん直に走り

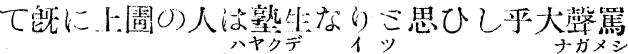

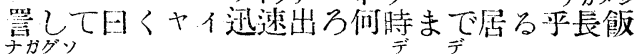

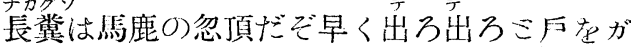
タガタ音響かすので余はオイオイえげぞえ だぞミ拇指を示せば前田は喫警頭を抱八て逃 げ行けり院長徐うに出來りて誰げ無法な事存 謂ふ實に困たナアこ在右の指在交互に揉みな がら田中速く山村(會計長)に上堛中外から戶 の開かぬ樣に栓を推へさせこ命じて吳れこて 歸られたり。

余は今院長の兩手学揉る〉を以て推測すれ ば壯年の前田は外から力まかせに戶觉引きし に院長ば夫はさせじミ內より左右兩手兑以て 力在極めて閉鎖に努力せられ焦めに左右の指 に疼痛を感じられしもの>如く余は恐懼に堪 へ古前由訓誡せんこ搜索せしに何處へ遁瓮 
し隱遁せし乎呼べミ゙も來らす影だも見せずな りにけり但し余の外には㜔る人なく此の一 幕の喜劇實演は他人に知れざりしこそ前田に 取りては幸福なりけれ。

\section{9. 空外朝櫻の眺矚}

明治二十幾年なり乙乎今は記憶に存せざれ ごも時維春陽櫻花閶漫東都は陽火の令辰さな りにし日余は當淔川口翁助先生ミ午後の延診 を共に乙新入患者の現症を學し終りて醫局に

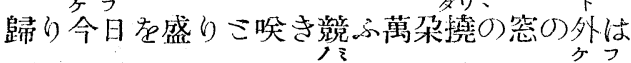
花に埋まる盛春を茶在喫ながら賞しつ>今日 はな圖らす此の春の量の花觀虑焦したりけり 然らば明朝は来明に起きて獨䦥雅の觀櫻も是

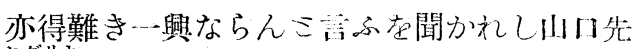
生左利の事なれば酒なくて茶を契み们の花見 かな事あれかしこ待ち居たる諧謔好きの事な れば由さらば明朝早く起き出て艘て居る夜具 在引剝さん若亦我身米忙しならば君夫れ我存 引剝せミ打興し共に喫茶に時移りいざやミ筬 して講堂の己が書硬に歸り來りぬ。

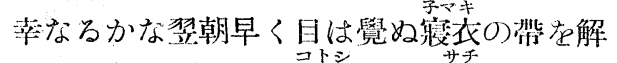
きながら密の戸開けば今歲ば花の荃深く雨さ 一降らす喛かく色麗はしく唋きも終らす散り

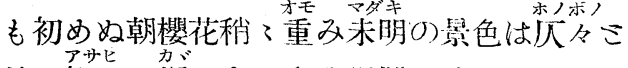

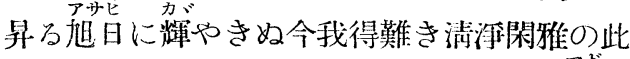
の花觀一句なくんばあらざるべからすこ空の 外眺めて推敲に餘念なかり乙折柄何時の閒に かは來玉へけん佐先生盛花の春に見取れてや 研究會場の外壁に添ひ此方へ步み在移し玉。 に遭遇せり余は喫警身を引き壁に瓮れしに恩 師も亦余は今猡衣の紐学解き放し前面裸體の 奇形に警き跼踏して何れの處一行かれけん最 早影䧔に見えざりけり。

整くして山口先生齒刷毛劣含みて來られた り余は佐先生意外に早きを劦質ぬれば昨日熱海 に往診せられ夜汽車学以て歸宗せられしも出 勤の時刻未狆至らす䉆めに花觀登䉆玉ひしな らんこ聞き始めて不時來院を詳かにせり蓋此 の喜劇の一幕は奇中の奇なりしも幸他に觀し
人なきは誠に僥倖なる次第なりけり若夫れ山 口先生の知るこころこならん乎又是尾に鯺军 附けて病院中の評制ミなりたるや必せり鳴呼 危いかな。

\section{0. 是は何の器械だらふ}

豐田常雄君日清戰等後臺灣に渡り居るここ 4,5 年歸り來りて自家使用の醫療器械を工進 社に命じて營縜せしめんこ欲し呼究會事務所 の)・側に占新聞名敷延して載せ置きしに鏡老 人ミ高橋氏ミ醫療器械には種々の形體有す る物ありミ兩人見てありしが䠶て高橋氏は鴨 りを攝りて是は们の器械げらふ恰も第 の゙嘴

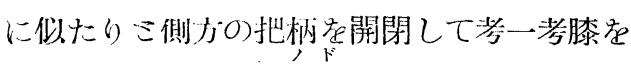
打ちて曰く是に必亦咽喉学觀る物ならんこ鏡 老人贅成して曰く成程成程こ高橋氏は余は今 ロ內に入れるから君見給へこ鴨口を取りてロ 内深く插入して把柄を開閉すれば鏡老人成程 熊く觀へ々今度は私が遣るから君見玉人气变 ア口内人插入!て居る所人豐由君歸り來れば 高橋氏は此の使用法を閣ふ曰く子宮鏡なり殊 に臺灣の媱賣婦を檢梅し最早歸京營縉するか らこ思ふて洗淨せざりしが故に夫れを羿るこ

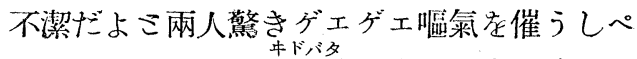
エペエ隀液を时き井户端に走りて含嗽清洗し 歸り來りて徽毒の感染を恐怖し居るこそ可笑 けれ。

\section{1. 山口先生の諧謔に照山君黃金を吐く}

維時明治 27,8 年日清戰役進先生留守中の 事なりき歲には敢て關係なきこ今年は殊に孟 夏釀暑し篤めに手術場裡は䈭懊こして恰も留 中に在るが如く人皆藓風定欲して流汗に苦し むの日であつた乃此の日の午後脫肛患者を呼 び出し手術臺上の人こなし全身麽醉を待つて 山口先生股間に坐せらる>や熟生照山は先 生の後方左側に趽踞し肩上から無意に開口し て一心に親覤き居れり其の後方傍觀臺上には 通生女醫の天田は暑さに堪へ難きやありけん 睡自に患者党一見しナンダ脫肞の燒灼か詰ら

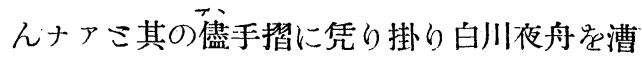


ぎ居たり斯くて山口先生「ネラトン」痔核拑子 存手にして將に弛緩粘膜学引き出さんこせら る>や忽ち肵內雷鳴あり此の時迅速先生身学 引き左側入避難らるっこ同時に水㴧一發夥多 黃金液を迸出せしかは何かは以て溜るべき照 山君は頭部から顏面から口内迄黃金塗しこな りにけるが其の餘波飛んで後方の天田の顏面 一撒布せり㓍に於て乎場內傿めに騷然たり照 山君は大口開いて急いで決水槽へ走らんこせ しに例の諧謔家の親玉山口先生は兩手を廣げ て照山を遮ぎりオイ时中君速く寫生をして吳 れ王へ此の大口開いた黄金塗しは前代未聞の 珍省像な゙速く々々こ謂ひながらマン照山暫ら く佇つて吳れこ押し止められ照山は口内の黃 金在此處へ昨き出すここも出來す只本鲐の如 く脹々こ山口先生蛋撥除んこあせれごも川口 先生はマアマア少し佇て最少しく支八止めら る哥笑さに皆々腹を抱へて焱ひ興ぜしも照山 自身は笑ひごには非す奥さは臭し氣持は湎 るし口內の黃金水は喠液に混して舞了㱠ゆれ

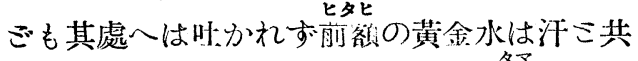
に眼の中へ流れ入らんこ煘るに最早堪らす手 で拭ひ其の手で山口先生営撥除けんこするの で之には流石の山口先生之や卟はんこ逃げ出 せしに此の時なりこ照山は決水槽へ走りゲェ ゲェ污物を明き出す其の側らに女䣽の天田は 濑やくに顏を洗ひ口を嗽き終りしも今照山の 顏面を見て我身も斯くぞ有りたるか心思一ば 胸が瀶氣なり腹も込上げて泣かんばかりの㭲 貌を見るに見かねて皆諸共に今は兩人の心を 推して人の難儀を笑ふべきかは、いこ氣の毒 こ矮はりて獎撫むるこそ目出たけれ。

\section{2. 三人上戸}

往時治承元年大納言成親卿は本家を減さん こ謀り乙際丹波の少將成經, 本制官康賴僧西 光等こ法勝寺の執行俊寬が鹿ケ谷の別莊に會 せ乙時席上の瓶子轉倒せしかば篦皆謂はく瓶 子の倒る〉は吉兆なりこ康賴曰く首定列るは 檢非違使の役なりこて瓶子学柱楹に縛して破
碎せり之は是勤王志上の宴會席上歡喜溢越の 酒興なりしが是に反して順天堂の會計員沼田 伊八こ西尾彭三ミは興に乘じて飲酒を領らん こ欲し〉に德利倒れて悲靯に吳れ遂に飲ます 食はざる三人上彌次喜太的の滑稽逸話党喚 起せるこそ可笑けれ。

時は維明治の二十幾年なりて乎余は今記憶

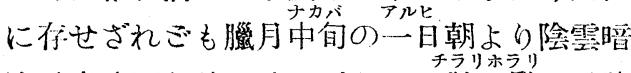

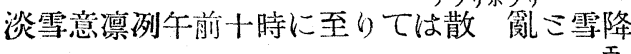
り出だし午後二時頃には會計局前の櫻樹は萬 条も撓に堆積して陽春三月の盛花を疑はしむ 誰か言ふ此の美麗の需惥死望觀するには只で は惜い湯豆腐で一杯遗りたらんには復一段の 興こそあらめこ沼田伊分西尾彭二の爾人は酒 こ聞ては默して居られ亦何事を私語合ひし乎 西尾はいそいそ門外に走り暫くありて嬄升德 利を提げ歸り會計電話器の下方に坐せし沼时 に渡し再び急ぎて出行きしは豆腐屋ならざれ ば恐らく看屋なるべし。

此日院長は坊空内の知人在訪ひ歸り掘れて 今此處に出來り「才イ沼田喜助 (車屋の親方) に急いて本宅渠車察命じて吳れ沼时は突然院

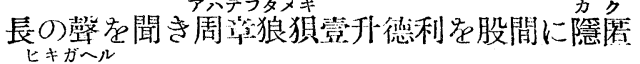
し蟾蜍の如く兩手突突きて命学聽き居りしが 如何がしけん德利は倒れて酒皆流出し忽ち座 下の洪水こなる院長警き沼日は腰髓麻㴓を 發起して尿失禁を第したるにはあらずる乎さ 思ひ互ひしならん乎「オイ沼田如何した乎大 變な水ではない乎「へイへイへイへイではな い上矢れが分らん乎手を擧げて見よミ沼田は 仕今なくなく右手を膝に上ぐれば装謀らん哉 股間から一升德利の轉がり出しに院長始めて 其の意を覺り笑を忍び急ぎて醫局へ去り行き 匡ひぬ。

玆に至りて沼田は濑やく立擧れば腰下半身 袴も衣服も足袋も「ズボン」下も悓鼻褌こ共に 酒に浸りて點滴り落るこミ雨滴の如し時に 嫏下に项音あり沼由は院長再來ならんこ急 いで會計宝の西北隅に恰も蝙蝠の壁面に附著 
せしが如く背面を露出て隱れ居たり此の時西 尾は整音高く歸り來りて宝內に入らんこ䉆れ ば何ぞ圖らん哉薰酒芬々鼻を打ち德利は轉倒 して疊は一面に酒浸しこなりをれり西尾警愕 奇罄学して是やまた如何したんだらうこ早 速德利を取りて振り動かせごも更に音なし失 望落膽一態沼田君は何處へ行たらふ「オイオ イ此處に居る妇已は復院長かこ思ふで喫”整し た「一態如何したんだ其の恰好はこ是より前 談炎話して西尾は漱やく其意を詳にし〉も獨 沼田は寒氣に堪八一方漱やく袷こ帶在解き放ち しも着換ゆるに衣服なく寒は增々加は〉りて

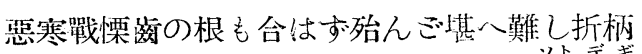
友公 (會計の小使) 歸り來り忽ち自己の外出着 取出して着せしめしも如何せん此の友吉は 年こそ 50 以上なれ身の丈低く亦從つて瘦 形 なるに沼日は金丈は晋通なれごも酒呑みの常 こして肥霂せしが故に桁丈は短くして恰も寺 古屋の多涎流に彷律たり。

此の時余は山口哿助先生: こ共に午後 3 時の 廻診を終りて會計局の前に來りしに腺內騷然 たるを以て障子范開けば川口先生沼日を一見 するや否や值に空内南方の壁際に至りオイ沼 田君此方に向ひて兩专在在右に伸して大の字 なりになりて罗玉、ウンそうそうこ雨手で 凩綡友手操が如くし「ドゥダ日中君此の奴凩 は好く出來て居るではない乎サア速く寫生し

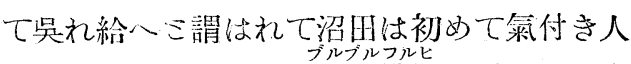

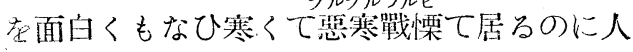
の氣も知らすにこ汸聲を出せば西尾は東奔西 走吞まんこ欲ひし酒は流れて覔ず事能はずブ

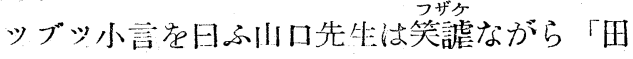
中君此の彌次喜太の䉆めに速く狂歌在狂歌党 こ促され余も亦是に鈞り込れて取敢す。

かくしたる德利倒れて酒びたし 沼四に陷ちて濡れしごこくに

忰めはこれ幸ひこ泥醉 おやじは香ひ嗅ぐのみにして

\section{3. 杏林逸話}

此杏林逸話は嘗て昭和 9 年禪界の雜誌道 友から寄稿を請はれ記して以て贈呈せし物 にして敢て順天堂に關せざれごも事は醫界 の逸話なりしを以て玆に餘錄こ䈍!て再び 記載する事こはなしぬ。

今は羔德川の末世天保年間紀伊の國（若山 縣）に名㱯ありけり，萧岡隨檕こ稱す，名は 震子は伯行靑淵に號す, 闌法㣽び漢法の醫術

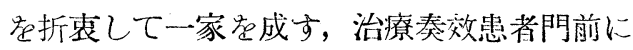
滿つ。

\section{釣客魚を釣らんと欲して自己を鈞}

一日壯丁あり，治を請ふて曰く，奴は釣焦

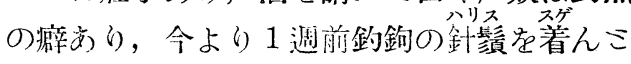
欲して釣鈎管口裡に含む，偶了一兒童あり，

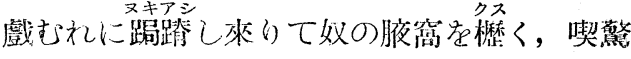

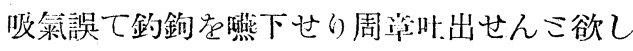
に其鈞鈎却て咽喉に等刺し針䰅に楊軟にして 如何こもするここ能はず爾來领食意の如くな

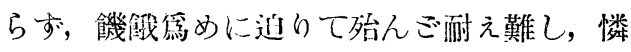
憫以て速に拔去乙給治んここ些こ先生現症を 觀祭し門人に命じて佛壇から念珠学持來らし

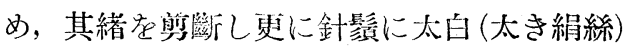
在連結し先づ地藏球子(念珠の中央に存する 第一大球子なり）を採りて，太白に貫き次て 小球子在聯經し用意解に成りて阿人をして頭 部蛋固定せしぬ，左指に下顎を厴し右指を以 て固く其䋨の外端を絞引し念珠の緒を緊張し て咽頭に问け衝突狀に壓下して其の釣鈎虔拢 き徐乃に引出して術を終はる，患者手術の輕 易に警き范然自失恰も鈎鈎を逃れし鮒の如く 暫時にして，我に復へり再生の高恩を謝して 歸郷の途に登りしこ云ふ。

蓋し患者は既に東贲西走一邀军費す。醫阨

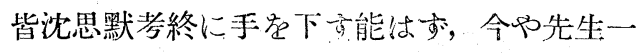
省牛慮の考案苯要せす忽ら拔去するここ神の 如し，鳴呼人閒賢愚の分岐立に在り，但し壯

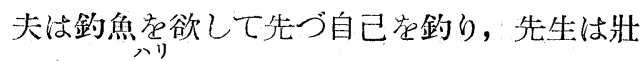
夫自鈎の鉤を拔きて以て䦓里に放て 6 ,

富豪の阿孃切られて却て生を得 
昔浪華 (大阪市)に一富豪あり，其の名人口 に膾采す。鴻池善五郎是なり。阿孃の背部に 癰炎發す。當持泰西の醫術未吾國一般に行は れす，又漢家に切開の術なし，若腫物を弡生 すれば, 敢て其の病症の如何军問はす，唯 䗨膏(猪脂に班猫を加人て製す俗に吸出心 も稱す）を貼し皮膚をして腐赨潰亂せしめて 以て排膿在促すのみ，故に癌倠の如き峰竹狀に 化膿して囊房を形成せざる腫物にありては却 て其刺戟に因りて㻐育增大し上て死亡を促進 するに過ぎす，當持此腫物を慄れしは現今の 腫瘍在恐怖するが如し，又偶了切開觉試むる 者ありしも今日の如く魔脺の䒚石なく復㳙毒 防噟の法あるなし，一朝不萃にして是范筑す れば手を束ねて望觀坐視するの外なきなり。 乃ち萧岡先生の等名天下に霜く，豈何ぞ故な きにあらん哉。而して鴻氏の主人使芷紀州に 走らし䰝虞うして往診を請ふ。先生仔細に 病症在聽取す。使者曰く主人死を怖れて切開 努欲せす，今遠く來りて治策先生に請。。意 立に在り，先生日く諾門第二人在從八共に浪 華溜氏の期に到る。歡喜擧つて先生:を迎ふ。

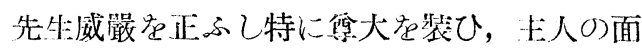
接を退けて日く，聽くが如きは患者の病症甚 重し，瞬持も忽にすべからず，值に狱室に

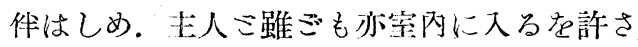

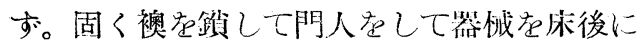
整頓せしめ患考の衣服を脫し眼党以て門人を 使役し，直に切開して，更に蜂案空槛切し綿 散絲(當時綿紗なし) 在貼し繃帶を施して少在 終はる。然り而して先牛初めて上人を呼びて 日く，余若初めに公こ面すれば切開を拒まる >や必せり。此の腫物にして切開せざるが如 きは發熱苦悶の結果虛脫に陷り，鬼籍に登る は火先見るよりも明なりミ，徐ろに病症の腎 性在詳說し却て其生命全き学得たる在㒭せら る。鴻家の春族此語を拜聽し其用意周到目.其 慈悲に感泣し高恩謝するに語なく唯感淚に咽 びて币頭拜謝するのみなりしこ云ふ。

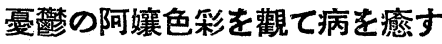

富豪の一女縣㖁の症を患ふ。一室に閉居し て人に面接を娧忌し志想芷縱にして悲泣袂を 濕ほす。其狀殆んぶ常識にあらず，父母憐臀 放擲する能ばす，醫治を涉獵せしも其效を見 す。人あり告げて日く城下に名醫あり華岡隨 軛先生こ稱す。其奏效に至りては耆婆扁鵲も 办三舍を避くこ，父母欣扑雀躍直に人を遣は

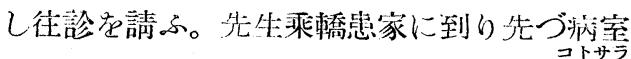
の人步退けて, 既往現症の自覺を間診し, 故意 に微笑点含みて暗に为症症輕易患ふるに足らさ るを裝ひ吏に閉月して其の療法を默考するも の>如くす，患者私かに先生の谷貌を覬顝

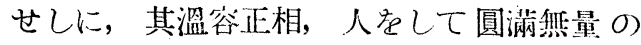
佛顏を拜するが如き感あらしむ，然り而し

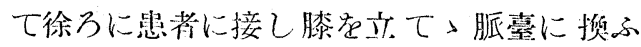
(當時の大家誩脈の際脈壹こ稱するものあり

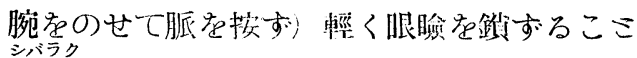
整時, 復他側の膝走立て 䇏脈前に異なるこ こなし，次で胸腹其の他蛋診して曰く，此の症 氯結に因る, 敢て憂ふるに足らす, 然りこ雖る゙

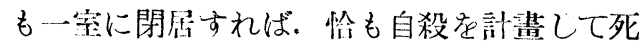
在待つに異ならす，如此きは師ち神佛も亦其 の不孝不戦を腎み，閻魔の朝に導きて日々に 呵責觉加ふ，其の狀地獄繪畫の圖の如し，鳴 呼怖るべし，慄くべし，故に治すべき疾病は 速に治療荍加へずんばあらざるなり，而して 余は今日投藥の他別に日課を授く，先づ庭內 胥緩步して下肢の力を恢復し次で神社佛閣に 參詣して䊆往の惡行足怴悔し或は墓參に租先 の冥福を祈禧すれば生前の企望も亦一こして 達せす心謂ふここなし，假令多量の樂石を飲 用するも醫命在固守せざれば何の效か之あら ん哉こ，噘命一番養生を命じて病室を出づ, 患者先生觉揆り床上に歸りて忽ち面を覆ひ笑 を禁ずる能はさざるもの>如し，侍女其所以を 尋ぬれごも敢て語らす，是より病勢日々に減 退し，食猃は却て日党追ふて元進せり，一日 乳母來りて病存訪ふ，低聲他言を警忌して曰 
く, 先生診脈に際し膝を立つ, 右側祍褊なく して䉐衣在隱見す，其色日々に異なり或は 紅, 或は黃, 或は紫, 或は綠, 或は藍, 其色 彩今简目に在り，あの威容嚴然たる老先生に して此の好事の命檘あり，恏れんこ欲するも 亦能はすミ，乳母も亦奇学好さの辟あり，先 生の來診を待ち窥覞せしにはたして然り，蓋 乙先生に於ける此の奇行は敢て他意あるにあ

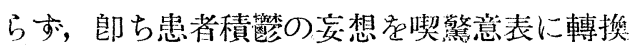
して其氣結を一揥せんこ欲するにあり，今や 患者は先生の俊虜ミなり, 㓌かに冥附の苛責 を戰慄し, ‘獨不孝を揁み，內に在りては乳母: こ褌衣の批評談笑に妄想を掃ひ，外に在りて
は神佛墓參の步行に疲勞して, 夜は熟睡以て

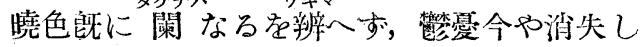
精神全く舊に復し，姿容の纖獀秀爽して濯々 春柳の如く顏貌の憔瘁は姱變して奸々櫻花の 如し，立に於て乎親子共に再生の高恩を謝 す, 蓋北齊の惠恩禪師聅あり, 自念して曰

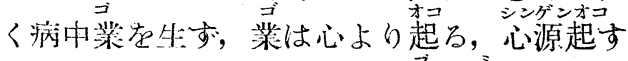

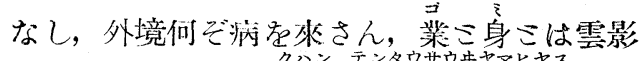
の如し, 如是く已灰觀じ顛倒想威病安きここ 故の如し, 使ち起ちて行くこ云ふ, 而てし隨 軒先生O少百人等頭一步を拔く，易に云く機 些罗て作る夫神乎

(完)

\section{順天堂醫事研究會例會}

昭和 13 年 10 月 12 日

1. 原發性腹腔妊娠に就て 吉賀一夫君

2. 所謂顆粒細胞消失症の 3 例に

就て

松本 本松君

3. 䣽學「トーキー」供德

生理的及病的體音供聽

東京醫學寫真協會
昭和 13 年 12 月 15 日

1. 囊包蟲病に起因せる肺壞独に 就七 小出 敏治君

2. バセドウ及非バセドウ币狀腺 腫の話

中山 笺樹君

3. 柴笛O行衞 松本 本松君

4. 氣管支擴張症O外科的療法

佐藤清一郎君

\section{内科抄讀會記 事}

昭和 13 年 9 月 16 日 (第 122 包)

任藤要(內科) 抄

\section{「ロベリン」に依る血液循環時間}

\section{測定法}

L. STANOJEVIC: Die Bestimmung der Kreislaufzeit mit Lobe-

lin. Ztschr. f. Kreislaufforschung $30 \mathrm{Jg}$. Heft 14, $15 \mathrm{Juli}, 1938$.

體重 1 瓦に對し $0.03-0.07 \mathrm{mg}$ の「ロぶリ ン」写静脈內に注射して血液循環速度空測定
する方法は心臟血管系の狀態を客觀的批判に 好適である。「ロべリン」の注射により惹起さ れる效果師ち咳嗽は客觀的であり明暸であり 且又瞬閒的である事は, 從來使用せられたる 諸法の圭觀的症候に據點军置き，その發現が 多くは明暸を缺き瞬間的でないのに比較して 遙かに優秀である。又本法は全く無害且つ手 技が簡單である故に數日乃至數時間內に數司 反㠅して施行するも不耐忍, 蓄積又は中毒等 の徴候が認められない。而して此方法に低れ 